\title{
The microaerophilic flagellate Giardia intestinalis: oxygen and its reaction products collapse membrane potential and cause cytotoxicity
}

\author{
David Lloyd, ${ }^{2}$ Janine C. Harris, ${ }^{2}$ Sarah Maroulis, ${ }^{1}$ Giancarlo A. Biagini, ${ }^{1}$ \\ Robert B. Wadley, ${ }^{1}$ Michael P. Turner ${ }^{2}$ and Michael R. Edwards ${ }^{1}$
}

\begin{abstract}
Author for correspondence: David Lloyd. Tel: +44292087 4772. Fax: +4429 20874305. e-mail: lloydd@cf.ac.uk
\end{abstract}

1 School of Biochemistry and Molecular Genetics and Cellular Analysis Facility, School of Microbiology and Immunology, University of New South Wales, Kensington, Sydney 2052, Australia

2 Microbiology Group, School of Biosciences (BIOSI, Main Building) Cardiff University, Cardiff CF10 3TL, UK
Trophozoites of the microaerophilic flagellate parasitic protozoon Giardia intestinalis have only a limited capacity to detoxify $\mathrm{O}_{2}$. Thus, when exposed to controlled concentrations of dissolved $\mathrm{O}_{2}>8 \mu \mathrm{M}$, they gradually lose their ability to scavenge $\mathrm{O}_{2}$. In a washed cell suspension stirred under $10 \%$ air in $\mathbf{N}_{2}$ (equivalent to $25 \mu \mathrm{M} \mathrm{O} \mathrm{O}_{2}$ ), inactivation of the $\mathrm{O}_{2}$-consuming system was complete after $3.5 \mathrm{~h}$; during this period accumulation of $\mathrm{H}_{2} \mathrm{O}_{2}\left(3 \mu \mathrm{mol}\right.$ per $10^{6}$ organisms) and oxidation of cellular thiols to $16 \%$ of their initial level occurred. Under $20 \%$ air $\left(50 \mu \mathrm{M} \mathrm{O}_{2}\right)$, respiratory inactivation was complete after $1.5 \mathrm{~h}$, and under air $(258 \mu \mathrm{M} \mathrm{O})$, after $50 \mathrm{~min}$. Loss of $\mathrm{O}_{2}$-consuming capacity was accompanied by loss of motility. Use of the fluorogen 2,7dichlorodihydrofluorescein acetate indicated that intracellular $\mathrm{H}_{2} \mathrm{O}_{2}$ is produced at extranuclear sites. Flow cytometric estimation of the plasma membrane electrochemical potentials using bis(1,3-dibutylbarbituric acid) trimethine oxonol, $\operatorname{DiBAC}_{4}(3)$, showed that values declined from $-134 \mathrm{mV}$ to $-20 \mathrm{mV}$ after $4.5 \mathrm{~h}$ aeration. Incubation of organisms with $60 \mu \mathrm{M} \mathrm{H} \mathrm{H}_{2}$ for 10 min gave partial collapse of plasma membrane potential and complete loss of $\mathrm{O}_{2}$ uptake capacity; motility and viability as assessed by $\mathrm{DiBAC}_{4}(3)$ exclusion were completely lost after $1 \mathrm{~h}$. Inactivation of the $\mathrm{O}_{2}$-consuming system and loss of viability were also observed on exposure to singlet oxygen photochemically generated from rose bengal or toluidine blue.

Keywords: hydrogen peroxide, oxidative stress, reactive oxygen species

\section{INTRODUCTION}

The flagellate protozoon Giardia intestinalis is a worldwide cause of intestinal infection and diarrhoea, and especially in infants and the elderly, morbidity (Ortega \& Adam, 1997) and mortality (Shukry et al., 1986). The trophozoite infects the upper jejunum by attachment to the mucosal surface. Waterborne transmission occurs by ingestion of cysts (Craun, 1990), which survive for periods of months in freshwater ecosystems at low temperatures. Control of contamination of fresh water and supplies of potable water is achieved only with difficulty, due to resistance of cysts to chemical agents

Abbreviations: CCCP, carbonyl cyanide $m$-chlorophenylhydrazone; DCCD, $N, N^{\prime}$-dicyclohexylcarbodiimide; $\operatorname{DiBAC}_{4}(3)$, bis(1,3-dibutylbarbituric acid) trimethine oxonol.
(Winiecka-Krusnell \& Linder, 1998), and the probable existence of animal reservoirs (Smith et al., 1995).

The upper intestinal lining is well supplied with capillaries, and $\mathrm{O}_{2}$ concentration there has been measured at $60 \mu \mathrm{M}$ (Atkinson, 1980). G. intestinalis is usually regarded as an 'anaerobic' protozoon, and grown and studied as such in laboratory culture (Meyer, 1976). However, several observations indicate that this organism is a microaerophile (Paget et al., 1989, 1993). Measurement of $\mathrm{O}_{2}$ consumption as a function of dissolved $\mathrm{O}_{2}$ indicates that at low levels $(0-50 \mu \mathrm{M})$, the organism is capable of scavenging $\mathrm{O}_{2}$ (apparent $K_{\mathrm{m}}$ for $\mathrm{O}_{2} 6.4 \mu \mathrm{M}$ for the trophozoite). Above a threshold of $80 \mu \mathrm{M} \mathrm{O}_{2}, \mathrm{O}_{2}$ inhibits its own consumption. Changes in the balance of major fermentation products occur as $\mathrm{O}_{2}$ concentration is increased. Paget et al. (1990) found that anaerobically, alanine and ethanol were formed in 
roughly equimolar amounts, ethanol production occurred maximally at $1.0 \mu \mathrm{M} \mathrm{O}_{2}$, whereas acetate accumulation continued to increase to at least $46 \mu \mathrm{M} \mathrm{O}_{2}$. The intracellular redox state, as indicated by in vivo measurement of NADH, and the integrity of an EPRdetectable iron-sulphur centre are both highly sensitive to traces $(<0 \cdot 1 \mu \mathrm{M})$ of $\mathrm{O}_{2}$ (Paget et al., 1993; Ellis et al., 1993). Here we aim to define the limits of $\mathrm{O}_{2}$ tolerance of this microaerophilic organism, and to characterize the nature of the structural and functional consequences of accumulation of reactive $\mathrm{O}_{2}$ species.

\section{METHODS}

Organisms and cultures. Giardia intestinalis, Portland 1 strain ATCC 30888, originally described by Meyer (1976), was obtained from the Queensland Institute of Medical Research. Trophozoites were grown axenically at $37^{\circ} \mathrm{C}$, using TYI-S-33 medium (Keister, 1983; Edwards et al., 1989) but with complement-inactivated new-born calf serum at $10 \%(\mathrm{v} / \mathrm{v})$ Cultures were initiated by inoculating $15 \mathrm{ml}$ medium in polypropylene centrifuge tubes with $4 \times 10^{4}$ organisms $\mathrm{ml}^{-1}$. A $0.5 \mathrm{ml}$ air headspace was routinely employed. Growth was for $2 \mathrm{~d}$ and final cell numbers reached about $10^{7}$ per tube.

Harvesting. Tubes were chilled on ice for $20 \mathrm{~min}$ and then shaken gently to dislodge adhered trophozoites. Cell numbers were measured by counting on a haemocytometer slide. Cell suspensions were centrifuged at $1000 \boldsymbol{g}$ (3000 r.p.m.) for $4 \mathrm{~min}$ at room temperature in a bench centrifuge at room temperature. After washing once with phosphate-buffered saline $(\mathrm{pH} 7 \cdot 1, \mathrm{PBS})$ and recentrifugation, organisms were finally resuspended in PBS or in $0.31 \mathrm{M}$ mannitol solution (as indicated) and kept at $4{ }^{\circ} \mathrm{C}$.

Measurements of $\mathrm{O}_{2}$ consumption rates. Cell suspensions $\left(2 \cdot 2 \times 10^{-6}\right.$ organisms $\left.\mathrm{ml}^{-1}\right), 2 \mathrm{ml}$ total volume $(1: 1)$ in PBS were incubated at $37^{\circ} \mathrm{C}$ in a 'closed' $\mathrm{O}_{2}$ electrode vessel (Rank) with magnetic stirring (200 r.p.m.). Where incubations were performed at low $\mathrm{O}_{2}$ concentrations, a stainless-steel open $\mathrm{O}_{2}$ electrode system fitted with a Teflon-membranecovered $\mathrm{O}_{2}$ electrode (Radiometer) (Lloyd et al., 1979) was employed. A digital gas mixer (Lundsgaard \& Degn, 1973) was used to mix $1 \%$ or $5 \% \mathrm{O}_{2}$ with $\mathrm{N}_{2}$; after humidification by passage over moist filter paper, the gas mixture was passed over the surface of the stirred liquid vortex (stirring at 500 r.p.m.), enabling the $\mathrm{O}_{2}$ tension to be maintained at desired levels. Addition of substrates (e.g. glucose) or of inhibitors were made through a septum. To obtain the transfer constant, $k$, the value of $t_{1 / 2}$ for equilibration of buffer upon switching the gas phase from $1 \% \mathrm{O}_{2}$ to $\mathrm{N}_{2}$ was determined, then $k$ was calculated from the relationship $k=\log _{\mathrm{e}} 2 / t_{1 / 2}$.

Respiration rates $\left(V_{\mathrm{r}}\right)$ were calculated from $V_{\mathrm{r}}=k\left(T_{\mathrm{G}}-T_{\mathrm{L}}\right)$, where $T_{\mathrm{G}}$ is the $\mathrm{O}_{2}$ concentration in the gas phase, and $T_{\mathrm{L}}$ that in the liquid phase.

$\mathrm{O}_{2}$ concentrations in PBS were calculated from the airsaturation value for air at $37^{\circ} \mathrm{C}\left(250 \mu \mathrm{M} \mathrm{O}_{2}\right)$.

Measurement of cellular swelling. Changes in cell volume were monitored by following the time course of absorbance change at $550 \mathrm{~nm}$.

Confocal laser-scanning microscopy. A Bio-Rad MRC confocal system attached to a research microscope (1024-Leica DMRB) was used with an argon-krypton air-cooled laser at $448 \mathrm{~nm}$. Images were obtained with $\mathrm{a} \times 63$ oil-immersion objective (NA 1.38). Section thickness was $5.5 \mu \mathrm{m}$. The $0.3 \mathrm{~W}$ laser was used at $10 \%$ power to minimize photobleaching. Unless otherwise stated, organisms were washed and resuspended in $0.31 \mathrm{M}$ mannitol before observation using 'FITC' filters. Images were acquired on Zip disc and printed using an Epson 750 colour printer.

Flow cytometry. Forward narrow-angle light scatter, sidescatter and fluorescence were measured using a flow cytometer (Multi-Laser Sorter, MoFlo Cytomation) fitted with a Cicero or a Cyclops Summit version 2 operating software. Fluorescence of bis(1,3-dibutylbarbituric acid) trimethine oxonol $\left[\right.$ DiBAC $\left._{4}(3)\right]$ was measured using a water-cooled $200 \mathrm{~mW}$ $488 \mathrm{~nm}$ argon-ion laser (Coherent I-90). An interference filter (D530/540) was used for emitted wavelengths (Chrome Technology), together with a Hammamatsu Hybrid Photodetector (no. 957-06). The characteristics of 20000 organisms were accumulated routinely.

Flow cytometric measurement of plasma membrane potential. Plasma membrane potential was measured by flow cytometry (Krasznai et al., 1995), using the negatively charged fluorescent membrane potential indicator dye $\operatorname{DiBAC}_{4}(3)$. This dye distributes across the cytoplasmic membrane, according to the Nernst equation.

A calibration curve of fluorescence intensity (i.e. channel number) measured from stained cells vs extracellular dye concentration allows evaluation of membrane potential in $\mathrm{mV}$ using live cells by comparison with those in depolarized state. Rather than employing fixed organisms (Emri et al., 1998), heat treatment $\left(>80^{\circ} \mathrm{C}\right)$ for 3 min was employed in order to produce a suspension with zero plasma membrane potential.

Transmission electron microscopy. Washed G. intestinalis cells were fixed at $4{ }^{\circ} \mathrm{C}$ for $1 \mathrm{~h}$ in $0 \cdot 1 \mathrm{M}$ cacodylate buffer $(\mathrm{pH}$ $6.9)$ containing $1 \%$ paraformaldehyde and $2 \%$ glutaraldehyde. They were post-fixed with phosphate-buffered $1 \%$ $\mathrm{OsO}_{4}$ at $4{ }^{\circ} \mathrm{C}$ for $1 \mathrm{~h}$, then dehydrated with successive washes of ethanol: $50 \%, 70 \%, 90 \%$ at $4{ }^{\circ} \mathrm{C}$ and two washes of $100 \%$ at room temperature. The cells were embedded in Spurr resin. Ultrathin sections were obtained with an LKB Ultratome III and mounted onto $0.5 \%$ Pioloform (in chloroform) coated copper grids. The sections were stained with aqueous uranyl acetate and lead citrate. Grids were analysed using a JEOL $1210 \mathrm{~V}$ transmission electron microscope.

Assay methods. Thiols were estimated after reaction with Ellman's reagent $\left(5,5^{\prime}\right.$-dithiobis-2-nitrobenzoic acid) at $412 \mathrm{~nm}\left(\varepsilon_{412}=14700 \mathrm{l} \mathrm{mol}^{-1} \mathrm{~cm}^{-1}\right)$ (Ellman, 1959). Hydrogen peroxide was measured in a closed $\mathrm{O}_{2}$ electrode using catalase.

Materials. Toluidine blue and rose bengal (tetraiodotetrachlorofluorescein) were gifts from Mr Till Böcking and Dr Kevin Barrow.

\section{RESULTS}

\section{Survival of organisms in the presence of $\mathrm{O}_{2}$}

When washed suspensions of $G$. intestinalis in PBS $(\mathrm{pH}$ $7 \cdot 1$ ) were stirred under a gas phase of air, $\mathrm{O}_{2}$ demand decreased until inactivation of the $\mathrm{O}_{2}$ consumption system was complete after $50 \mathrm{~min}$ (Fig. 1a), when dissolved $\mathrm{O}_{2}$ reached the air-saturated value. Accumulation of $\mathrm{H}_{2} \mathrm{O}_{2}$ continued for the duration of the experiment $(195 \mathrm{~min})$, to reach $4 \mu \mathrm{mol}$ per $10^{6}$ organisms. Under $4 \% \mathrm{O}_{2}$ in $\mathrm{N}_{2}$, inactivation took $75 \mathrm{~min}$ (Fig. 1b), whereas under $2 \% \mathrm{O}_{2}$ in $\mathrm{N}_{2}$ it took 140 min; under $1 \% \mathrm{O}_{2}$ in $\mathrm{N}_{2}, \mathrm{O}_{2}$ uptake was still measurable 

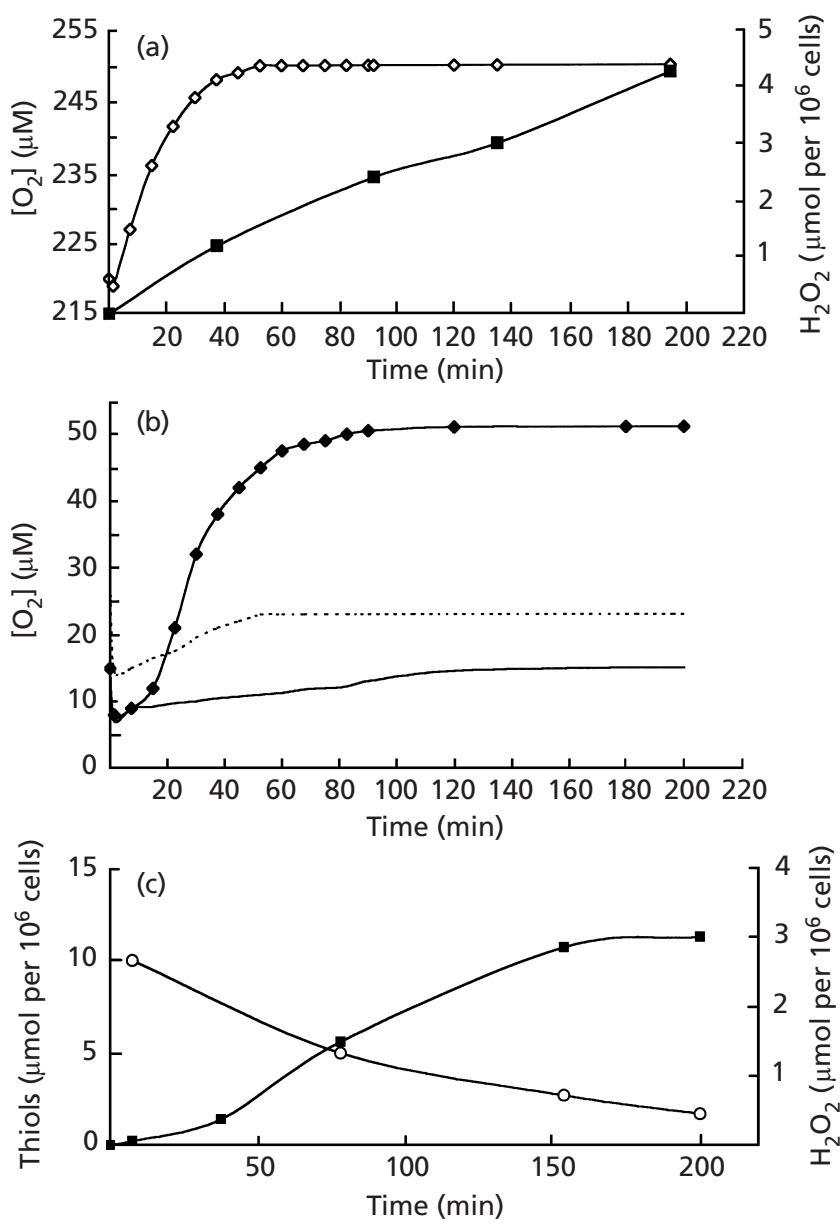

Fig. 1. Changes in dissolved $\mathrm{O}_{2}$ during the inactivation of $G$. intestinalis $\left(10^{6}\right.$ cells $\left.\mathrm{ml}^{-1}\right)$ by exposure to $\mathrm{O}_{2}$. Balances between $\mathrm{O}_{2}$ supply and demand resulted in increased levels as inactivation occurred until dissolved $\mathrm{O}_{2}$ became equivalent to that in the gas phase. (a) Dissolved $\mathrm{O}_{2}(\diamond)$ and $\mathrm{H}_{2} \mathrm{O}_{2}$ ( $\square$ ) accumulation under air. (b) Dissolved $\mathrm{O}_{2}$ under $4 \% \mathrm{O}_{2}$ in $\mathrm{N}_{2}$ $(\diamond), 2 \% \mathrm{O}_{2}$ in $\mathrm{N}_{2} \%(---)$ and $1 \% \mathrm{O}_{2}$ in $\mathrm{N}_{2}$ (-). (c) $\mathrm{H}_{2} \mathrm{O}_{2}$ accumulation $(\square)$ and depletion of cellular thiols $(O)$ under $2 \%$ $\mathrm{O}_{2}$ in $\mathrm{N}_{2} \%$.

after 4 h. Fig. 1 (c) shows the accumulation of $\mathrm{H}_{2} \mathrm{O}_{2}$ and the decrease in total cellular thiols (conversion from thiol to disulphide forms) when the organisms were stirred under $2 \% \mathrm{O}_{2}$ in $\mathrm{N}_{2}$. Cessation of $\mathrm{O}_{2}$ consumption under all conditions of exposure to inhibitory $\mathrm{O}_{2}$ concentrations preceded loss of membrane potential (see below), flagellar movement and cell motility. These changes were irreversible; restoration of anaerobiosis did not lead to recovery of cellular function.

\section{Structural changes under $\mathrm{O}_{2}$}

Fig. 2(a) shows a bright-field image of a population of washed $G$. intestinalis trophozoites in the presence of $1 \mu \mathrm{M} \mathrm{DiBAC}(3)$. The same field examined for fluorescence (excitation $490 \mathrm{~nm}$, emission $519 \mathrm{~nm}$; Fig. $2 \mathrm{~b}$ ) indicates that almost all the organisms exclude the fluorophore; those that do not are damaged. After exposure of organisms to $\mathrm{O}_{2}$ almost all the cells still excluded the fluorophore; again those that did not were damaged (not shown). Storage at $4{ }^{\circ} \mathrm{C}$ for $18 \mathrm{~h}$ (Fig. 2c) gave a population that was completely $\mathrm{DiBAC}_{4}(3)$ permeable. Organisms stirred under $5 \%$ air remained impermeable to $\operatorname{DiBAC}_{4}(3)$ for more than $6 \mathrm{~h}$, whereas under $10 \%$ air after $4.5 \mathrm{~h}$ many organisms became fluorescent. Confocal laser-scanning microscopy (Fig. $2 \mathrm{~d}$ ) indicated that $\operatorname{DiBAC}_{4}(3)$ had permeated the plasma membrane and the flagella. Under $100 \%$ air, $\mathrm{DiBAC}_{4}(3)$ penetration was rapid, occurring in less than $1 \mathrm{~h}$. Heatkilled organisms also became completely $\mathrm{DiBAC}_{4}(3)$ permeable (not shown). Exposure to air for $10 \mathrm{~min}$ (Fig. 2e, f) or incubation with $60 \mu \mathrm{M} \mathrm{H}_{2} \mathrm{O}_{2}$ for 10 min (Fig. $2 \mathrm{~g})$ gave organisms in which 2,7-dichlorodihydrofluorescein became oxidized to give fluorescence in the cytosol. The distribution of the fluorescence suggested that externally applied $\mathrm{H}_{2} \mathrm{O}_{2}$ also gave fluorophore oxidation in peripheral vesicles, which was not the case when organisms were oxidatively stressed in air.

\section{Flow cytometry of organisms exposed to $\mathrm{O}_{2}$}

Measurement of fluorescence of $\mathrm{DiBAC}_{4}(3)$-treated organisms showed that the population behaved uniformly towards agents that depolarized the plasma membrane potential and that oxidative stress, produced by exposure to air or by externally added $\mathrm{H}_{2} \mathrm{O}_{2}$, also had this effect. Fig. 3 shows two typical experiments. Live cells did not take up the anionic fluorophore, whereas heat-killed organisms were highly $\mathrm{DiBAC}_{4}(3)$ permeable and hence were counted in channels indicative of high fluorescence intensities. Other treatments known to affect ion transport processes and hence lead to partial collapse of the potential across the plasma membrane resulted in fluorescence emission values intermediate between those of active organisms and the completely depolarized dead cells. Cells aerated for $1 \mathrm{~h}$ (Fig. 3a, panel 5) and those treated with $60 \mu \mathrm{M} \mathrm{H}_{2} \mathrm{O}_{2}$ for 5 min (Fig. 3b, panel 2) also showed increased permeability to $\mathrm{DiBAC}_{4}(3)$. Plots of forward light scatter (a measure of cell size) vs side scatter showed that as cells became damaged by $\mathrm{O}_{2}$, they also progressively increased in volume (data not shown). Heat-killed organisms gave lower forward scatter signals than live ones. Pulse-width measurements showed that cell doublets or aggregates were rare for live, damaged or dead organisms.

Calibration of fluorescence intensity (channel no.) against $\mathrm{DiBAC}_{4}(3)$ concentration provides a means of measuring plasma membrane potential (Krasznai et al., 1995; Emri et al., 1998). Heat-killed organisms (with zero membrane potential, used as a control) were taken to have an intracellular fluorescence equal to that of dye in the suspending medium. Fig. 4 shows that live organisms when suspended in $0 \cdot 31 \mathrm{M}$ mannitol had a plasma membrane potential of $-134 \pm 3 \mathrm{mV}(n=6)$. Exposure to $5 \%$ air for $4.5 \mathrm{~h}$ decreased this value to $-100 \mathrm{mV}$, whereas under $100 \%$ air, G. intestinalis became almost completely depolarized in $4.5 \mathrm{~h}$. Effects 


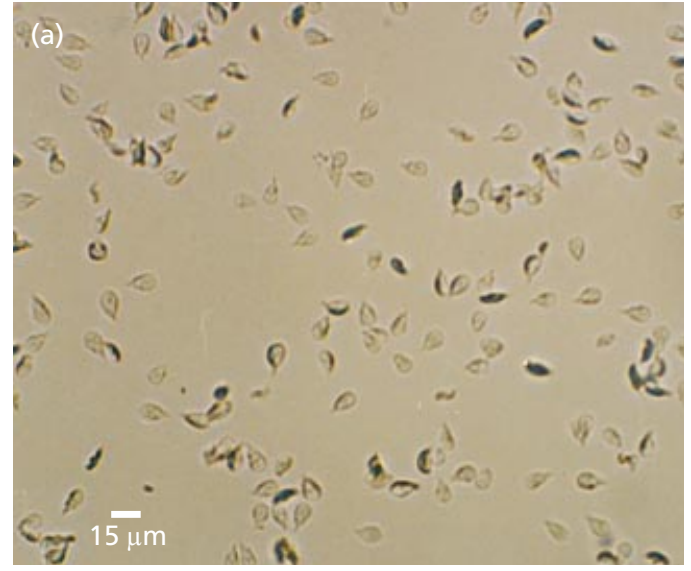

(b)

$15 \mu \mathrm{m}$
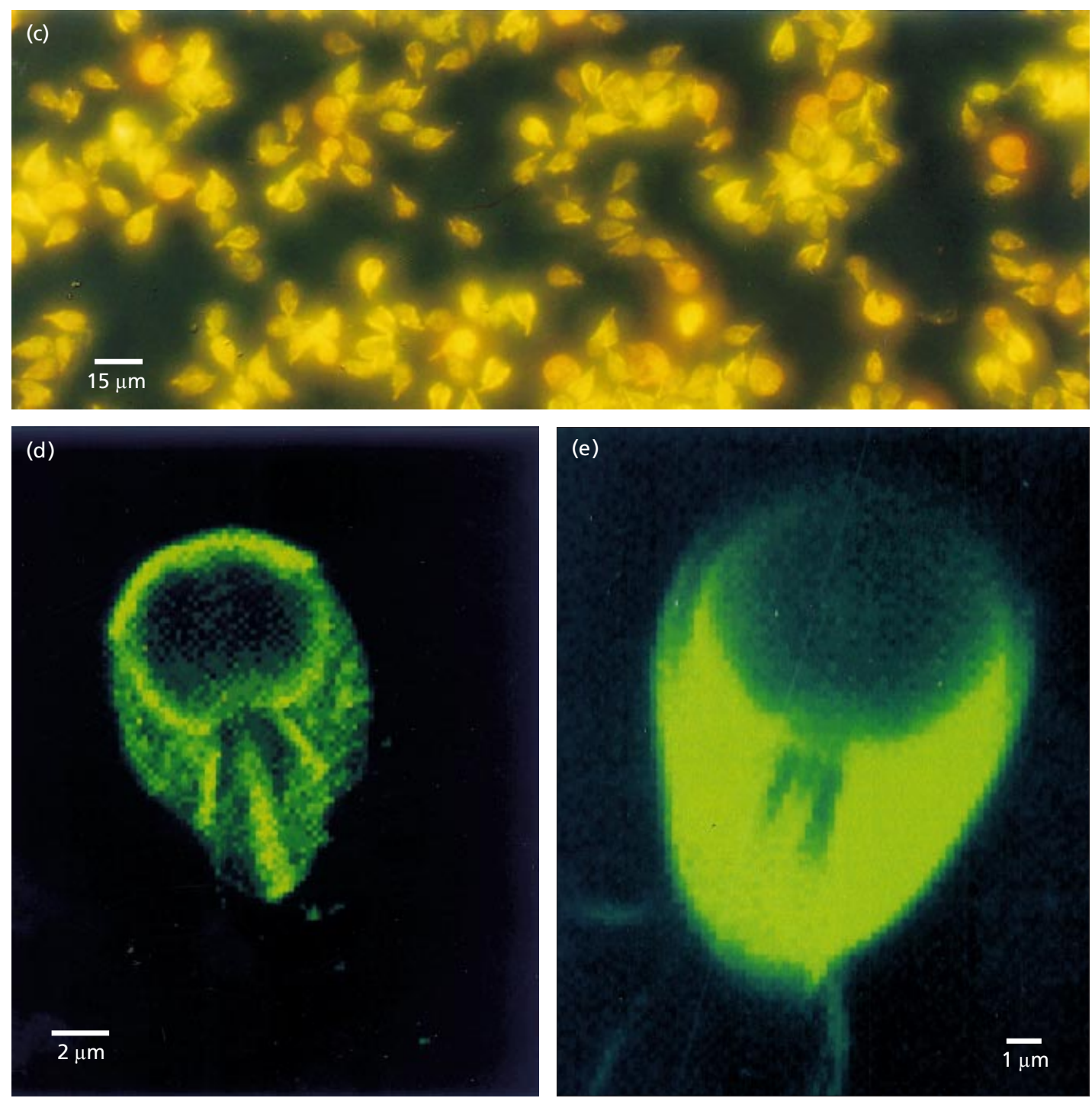

Fig. 2. For legend see facing page.

of some inhibitors are also shown: the most effective (albeit at high concentration, $100 \mu \mathrm{M}$ ), was the protonpumping ATPase inhibitor DCCD. Gramicidin $(1 \mu \mathrm{M})$, an ionphore acting to increase membrane permeability to $\mathrm{H}^{+}, \mathrm{K}^{+}$and $\mathrm{Na}^{+}$, or the protonophore CCCP $(10 \mu \mathrm{M})$ were both highly efficient at diminishing potentials. 

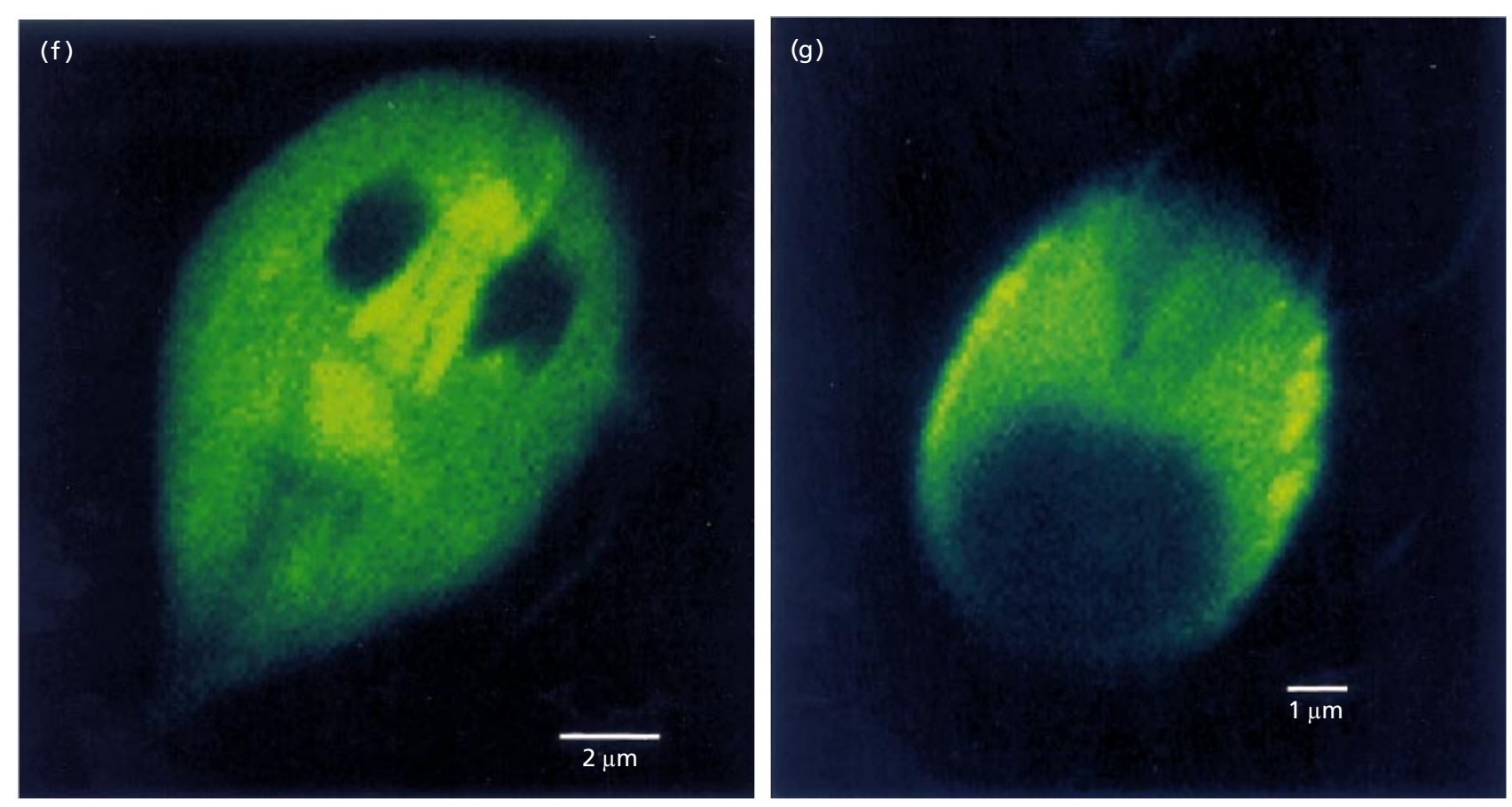

Fig. 2. Micrographs of $G$. intestinalis incubated with $1 \mu \mathrm{M} \operatorname{DiBAC}_{4}(3)(a-d)$ or with $2^{\prime}, 7^{\prime}$-dichlorodihydrofluorescein diacetate (e-g). (a) Bright-field illlumination. (b) Fluorescence (same field as in a). (c) Fluorescence after storage at $4{ }^{\circ} \mathrm{C}$ for $18 \mathrm{~h}$. (d) Confocal laser-scanning fluorescence image of an organism exposed to air for $4.5 \mathrm{~h}$. (e-g) Organisms incubated for $10 \mathrm{~min}$ in air (e, f; ventral and dorsal aspects respectively), or in $60 \mu \mathrm{M} \mathrm{H}_{2} \mathrm{O}_{2}(\mathrm{~g})$.

\section{Oxygen consumption measurements}

The effects of $\mathrm{O}_{2}$ exposure could be mimicked by addition of $60 \mu \mathrm{M} \mathrm{H}_{2} \mathrm{O}_{2}$ to washed cell suspensions in PBS: Fig. 5(a) shows its immediate inhibitory effect on $\mathrm{O}_{2}$ consumption. That ${ }^{\circ} \mathrm{OH}$ is produced when $G$. intestinalis is treated with $\mathrm{H}_{2} \mathrm{O}_{2}$ is indicated by protective effects of $\cdot \mathrm{OH}$ radical quenchers $(50 \mathrm{mM}$ sodium benzoate or $50 \mathrm{mM}$ mannitol); ferric nitrilotriacetic acid accentuates $\mathrm{H}_{2} \mathrm{O}_{2}$ inhibition. Similar results were obtained with a well-washed non-proliferating suspension of $G$. intestinalis in a reactor open for gas flow, under an atmosphere of defined low $\mathrm{O}_{2}$ value (Fig. 5b).

When the organism was illuminated $\left(400 \mu \mathrm{mol} \mathrm{m}^{-2} \mathrm{~s}^{-1}\right)$ during incubation with $2.5 \mu \mathrm{M}$ toluidine blue or $10 \mathrm{~mm}$ rose bengal under $5 \%$ air in $\mathrm{N}_{2}\left(=12.5 \mu \mathrm{M} \mathrm{O}_{2}\right)$, almost complete inactivation of the $\mathrm{O}_{2}$-consuming system was observed within $45 \mathrm{~min}$; after this time organisms were completely immobilized, and for rose bengal, they also became dye-permeable. Similar incubations under anaerobiosis in the light gave no cytotoxic effects.

\section{Electron microscopy}

All of the main distinguishing features of G. intestinalis can be seen in the controls shown in Fig. $6(a, b)$, i.e. the ventral disc composed of numerous microtubules, dorsal ribbons and cross-links with its rigid lateral crest, overlying ventrolateral flange and supporting marginal plates or striated bodies. The two equivalent nuclei lie lateral to the kinetosomal complex consisting of eight kinetosomes in four pairs. In the horizontal crosssection (Fig. 6b) the ventral and posteriolateral axonemes are visible along with the caudal axonemes. The anterior axonemes cannot be seen at this level but the anterior flagella can be seen external to the cell. All axonemes and flagella show the typical $9+2$ microtubule arrangement. The vertical section (Fig. 6a) shows how the anterior axonemes course anteriorly in the cell before crossing and moving posteriorly to emerge at the cell's widest point. These axonemes are accompanied by the striated bodies. The microtubules of the median bodies can be seen in their disorganized array. $\mathrm{Nu}^{-}$ merous peripheral vacuoles lie below the plasmalemma. The cytoplasm stains dark owing to the presence of numerous stored granules, e.g. glycogen.

Incubation with $60 \mu \mathrm{M} \mathrm{H}_{2} \mathrm{O}_{2}$ for 30 min brought about rapid morphological change and cell breakdown (Fig. $6 \mathrm{c}, \mathrm{d})$. Most of the cells were 'ghostlike', with no darkstaining material in the cytoplasm and condensation within the nucleus. Numerous peripheral vacuoles scattered beneath the plasmalemma on the dorsal surface were visible. These appeared to converge and burst the cell. The ventral disc, axonemes and kinetosomes remained intact, indicating that oxidative stress has no evident impact on microtubule structure.

After $1 \mathrm{~h}$ aeration, the bulk of the cells maintained the pyriform structure, but some cells became swollen and 
(a)
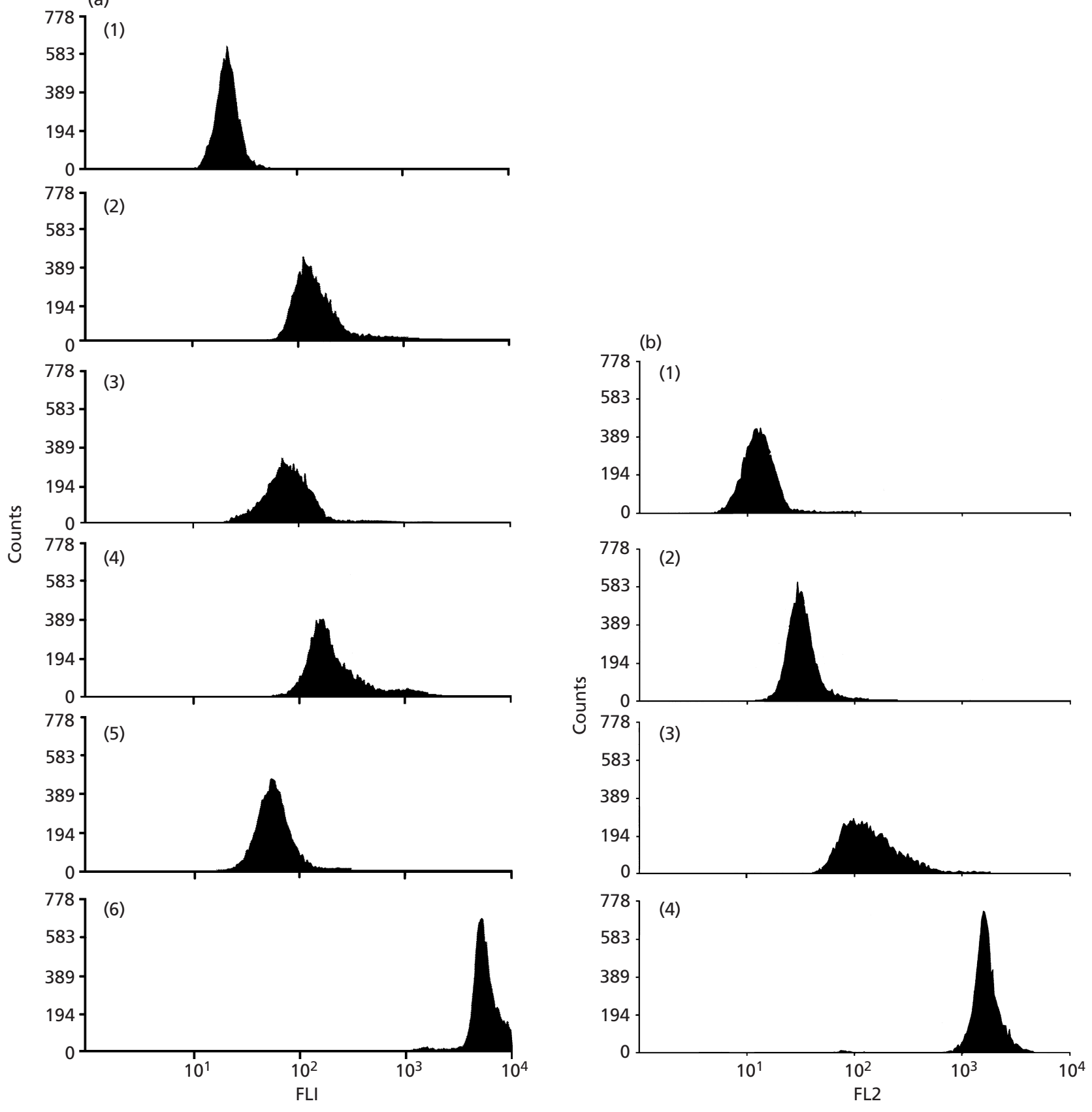

Fig. 3. Flow cytometric analyses of $\mathrm{DiBAC}_{4}(3)$-treated G. intestinalis. (a) 1, Control (live organisms). 2-6, Treated cells: 2 , $10 \mu \mathrm{M}$ CCCP; 3, $1 \mu \mathrm{M}$ gramicidin; 4, $100 \mu \mathrm{M}$ DCCD; 5, aeration for $1 \mathrm{~h} ; 6$, heat-killed ( $>80^{\circ} \mathrm{C}$ for 5 min). Incubations were with $0.31 \mathrm{M}$ mannitol/1 $\mu \mathrm{M} \mathrm{DiBAC}_{4}$ (3) for $30 \mathrm{~min}$. (b) 1, Control (live cells). 2-4, Treated cells: 2, $60 \mu \mathrm{M} \mathrm{H} \mathrm{O}_{2}$ for $5 \mathrm{~min}$; 3 , $1 \mu \mathrm{M}$ gramicidin; 4 , heat-killed ( $>80^{\circ} \mathrm{C}$ for $5 \mathrm{~min}$ ). Organisms were incubated in $0.31 \mathrm{M}$ mannitol/0.5 $\mu \mathrm{M} \mathrm{DiBAC}_{4}(3)$ for $30 \mathrm{~min}$. FL1 and FL2 represent the fluorescence emission in channel 2, at 530-540 nm.

misshapen (Fig. 6e). In all cells the ventral disc, its rigid lateral crest and ventrolateral flange were intact; no fragmentation of the disc was visible. The nuclei were no longer spheroid but appeared to have several cytoplasmic projections, and some had associated multilamellar bodies (Fig. 6f). The axonemes were intact and were still located centrally within the cell. The misshapen swollen cells had large cytoplasmic vacuoles and the dark granule-filled cytoplasm was now very sparse. They appeared 'ghostlike'. In these cells the ventral disc was still intact.

After $2 \mathrm{~h}$ aeration the number of swollen and misshapen cells had increased, yet many cells still remained pyriform in structure (Fig. 6g, h, i). Many nuclei had associated multilamellar bodies (Fig. 6h). The ventral discs, lateral crests and ventrolateral flanges were still 


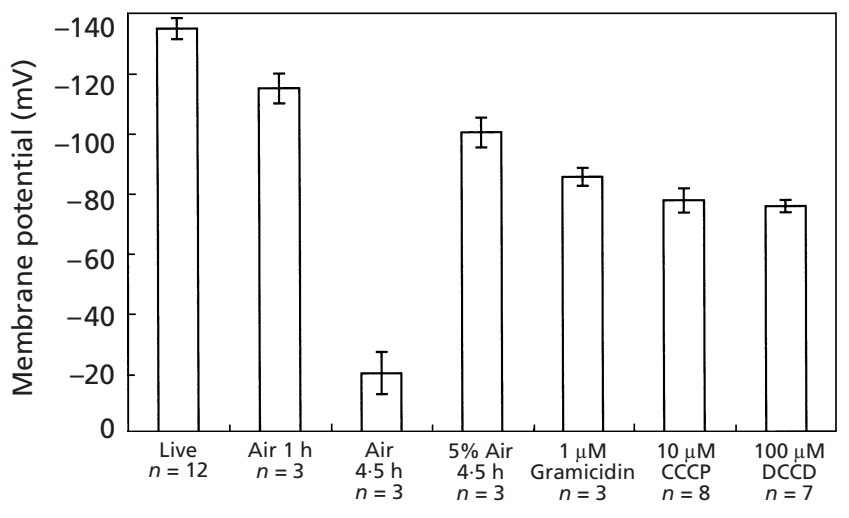

Fig. 4. Plasma membrane potentials of $G$. intestinalis as determined by $\operatorname{DiBAC}_{4}(3)$ permeability. Determinations were made over a range $(0 \cdot 25-2 \cdot 0 \mu \mathrm{M})$ of external $\operatorname{DiBAC}_{4}(3)$ concentrations.
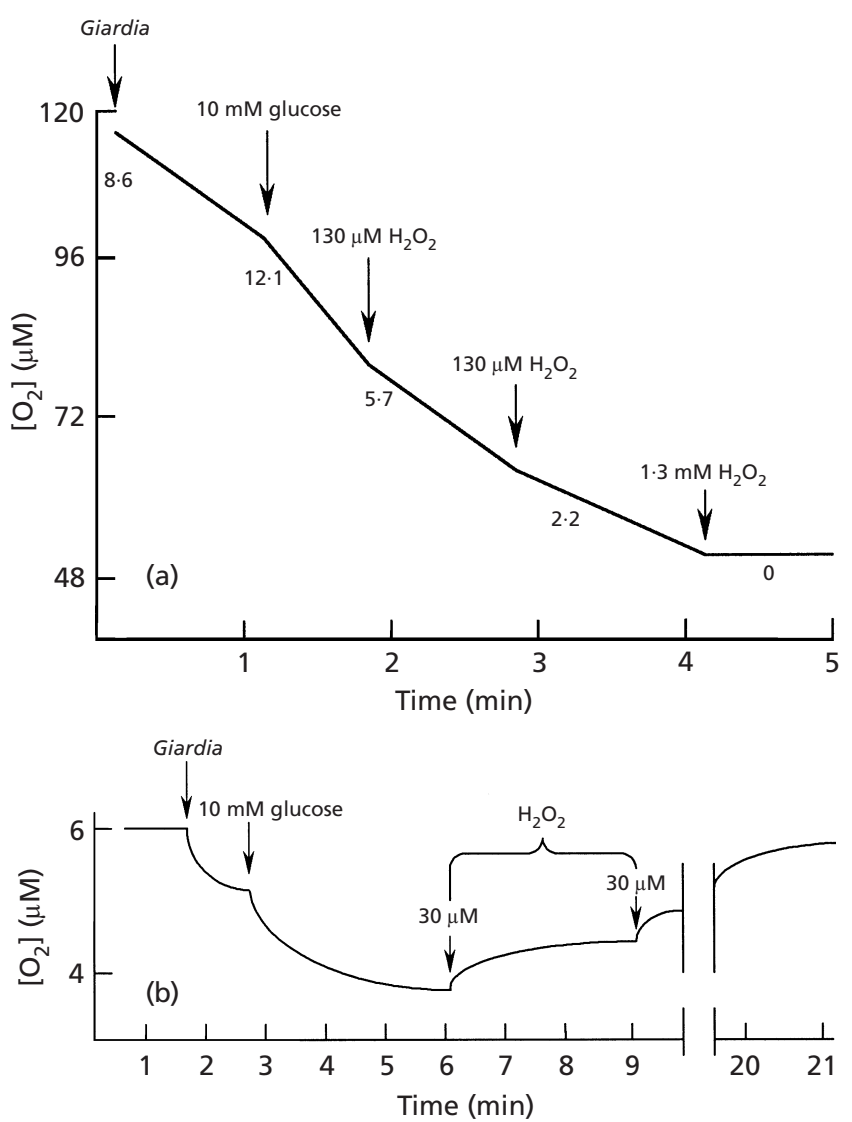

Fig. 5. $\mathrm{O}_{2}$ consumption by $G$. intestinalis; inhibition by added $\mathrm{H}_{2} \mathrm{O}_{2}$. (a) $\mathrm{O}_{2}$ depletion in a closed vessel fitted with an $\mathrm{O}_{2}$ electrode. Total reaction volume $1.1 \mathrm{ml}$, stirring at 200 r.p.m., $2.2 \times 10^{6}$ organisms $\mathrm{ml}^{-1}$. Numbers on the trace are $\mathrm{nmol} \mathrm{\textrm {min } ^ { - 1 }}$ per $10^{6}$ organisms. (b) Steady-state dissolved $\mathrm{O}_{2}$ in a vessel open for gas flow. Total reaction volume $6 \mathrm{ml}$, gas phase, $0.5 \% \mathrm{O}_{2}$ in $\mathrm{N}_{2}$ stirring rate 200 r.p.m., $10^{6}$ organisms $\mathrm{ml}^{-1}$.

intact. The cytoplasm was less dense and did not stain as darkly as previously. The number of peripheral vacuoles had increased.
After $3 \mathrm{~h}$ aeration only a few cells remained in the intact pyriform shape. Many cells had completely broken down and cellular debris abounded. The cytoplasm stained only weakly, with very few dark-staining granules remaining. Most cells were not recognizable as Giardia (Fig. 6j). The nuclei had broken down and their chromatin had condensed. The ventral disc and axonemes were still intact, suggesting again that oxidative stress does not affect the microtubule structure within the cell.

\section{DISCUSSION}

G. intestinalis has previously been shown to have a limited capability for withstanding exposure to dissolved $\mathrm{O}_{2}$ (Paget et al., 1989). In those experiments where the $\mathrm{O}_{2}$ dependence of $\mathrm{O}_{2}$ uptake were investigated, the concentration of dissolved $\mathrm{O}_{2}$ was increased from an undetectable level to $5 \%$ air saturation in a series of steps of $20 \mathrm{~min}$ each. Those data provide indications on apparent $K_{\mathrm{m}}$ values and of a threshold above which $\mathrm{O}_{2}$ became inhibitory. In the present investigation, we have systematically investigated the time- and concentration-dependence of the $\mathrm{O}_{2}$ effects during long-term maintenance of steady-state levels. Oxidative damage was shown, not only to the electrontransport systems responsible for $\mathrm{O}_{2}$ reduction, but to cell functions across a wide range. Thus damage to the plasma membrane, as indicated by the progressive loss of ability to exclude the anionic voltage-sensitive dye $\mathrm{DiBAC}_{4}(3)$ (Lloyd \& Hayes, 1995), led to swelling of organisms and loss of the regulatory volume control process, described in fully functional organisms (Park et al., 1995). Sites known to be $\mathrm{O}_{2}$-inhibited in $G$. intestinalis include a $(4 \mathrm{Fe}-4 \mathrm{~S})$ iron-sulphur cluster (Ellis et al., 1993) and redox-active thiols involved in volume regulation (Park et al., 1995). The fact that these effects could also be produced almost immediately by $60 \mu \mathrm{M}$ $\mathrm{H}_{2} \mathrm{O}_{2}$ suggests that exposure to inhibitory levels of $\mathrm{O}_{2}$ results in accumulation of this partial reduction product. The Fenton Haber-Weiss reaction is then free to produce ${ }^{\circ} \mathrm{OH}$ from $\mathrm{H}_{2} \mathrm{O}_{2}$ and ${ }^{\cdot} \mathrm{O}_{2}^{-}$, especially as this organism contains no detectable superoxide dismutase (Smith et al., 1988), peroxidase or catalase (Brown et al., 1995). Enhanced loss of functional activity in the presence of ferric nitrotriacetic acid (Aruoma et al., 1989) and diminished inactivation in the pressure of the - OH radical scavengers, sodium benzoate or mannitol (Halliwell, 1978) suggests that ${ }^{\circ} \mathrm{OH}$, a radical known for its extremely damaging reactivity (Halliwell \& Gutteridge, 1989) may be an important intracellular oxidant in these experiments. The $\mathrm{O}_{2}$-dependent production of photo-emissive species in Giardia lamblia has been demonstrated (T. Paget \& D. Lloyd, unpublished data). These species, observed as low-level chemiluminescence in organisms metabolizing glucose, could be greatly enhanced in the presence of the redox-cycling naphthoquinone menadione. The fact that the oxygenconsuming redox chains of organisms can be damaged by ${ }^{1} \mathrm{O}_{2}$-generating systems, the photodynamically acti- 

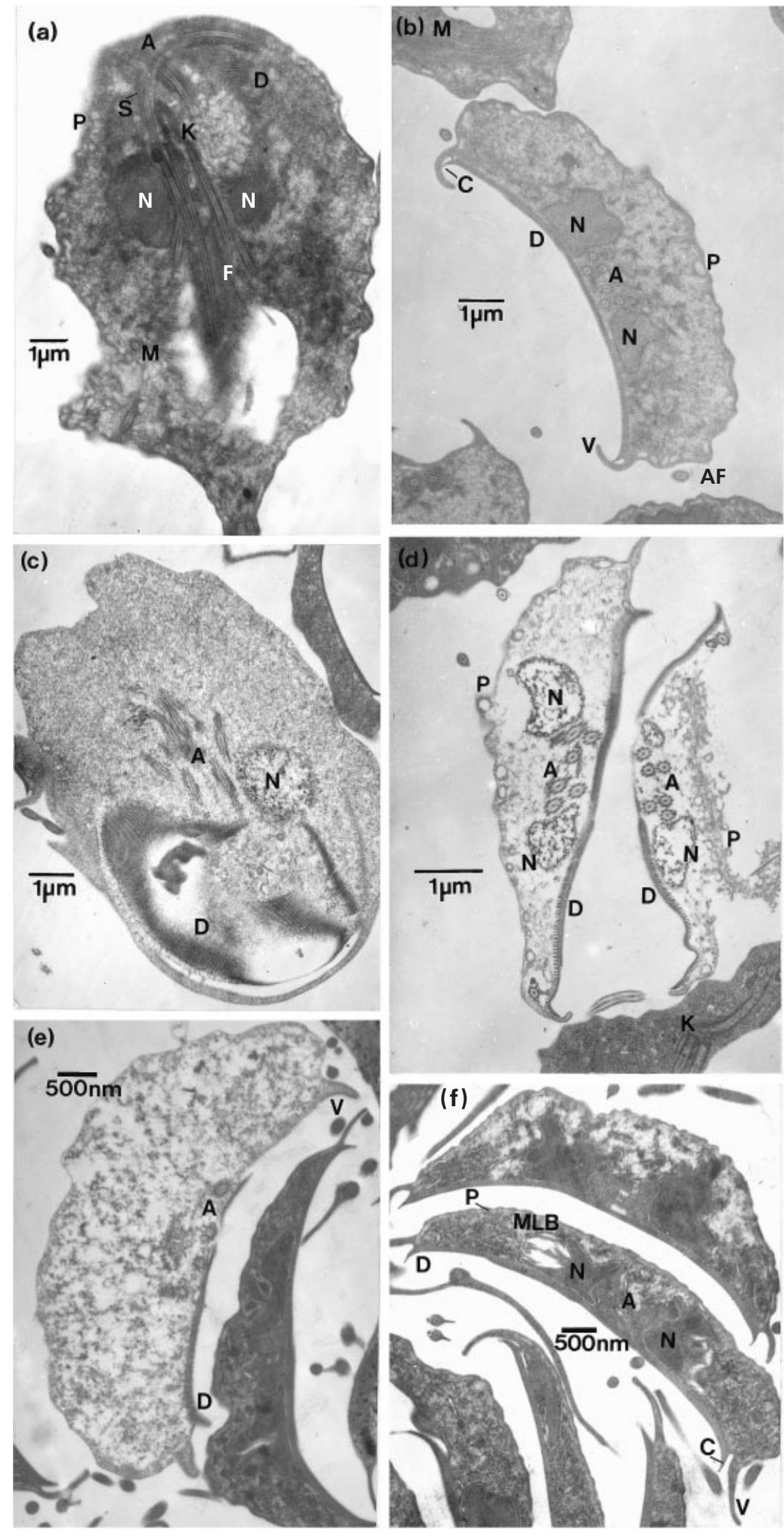

Fig. 6. For legend see facing page. 


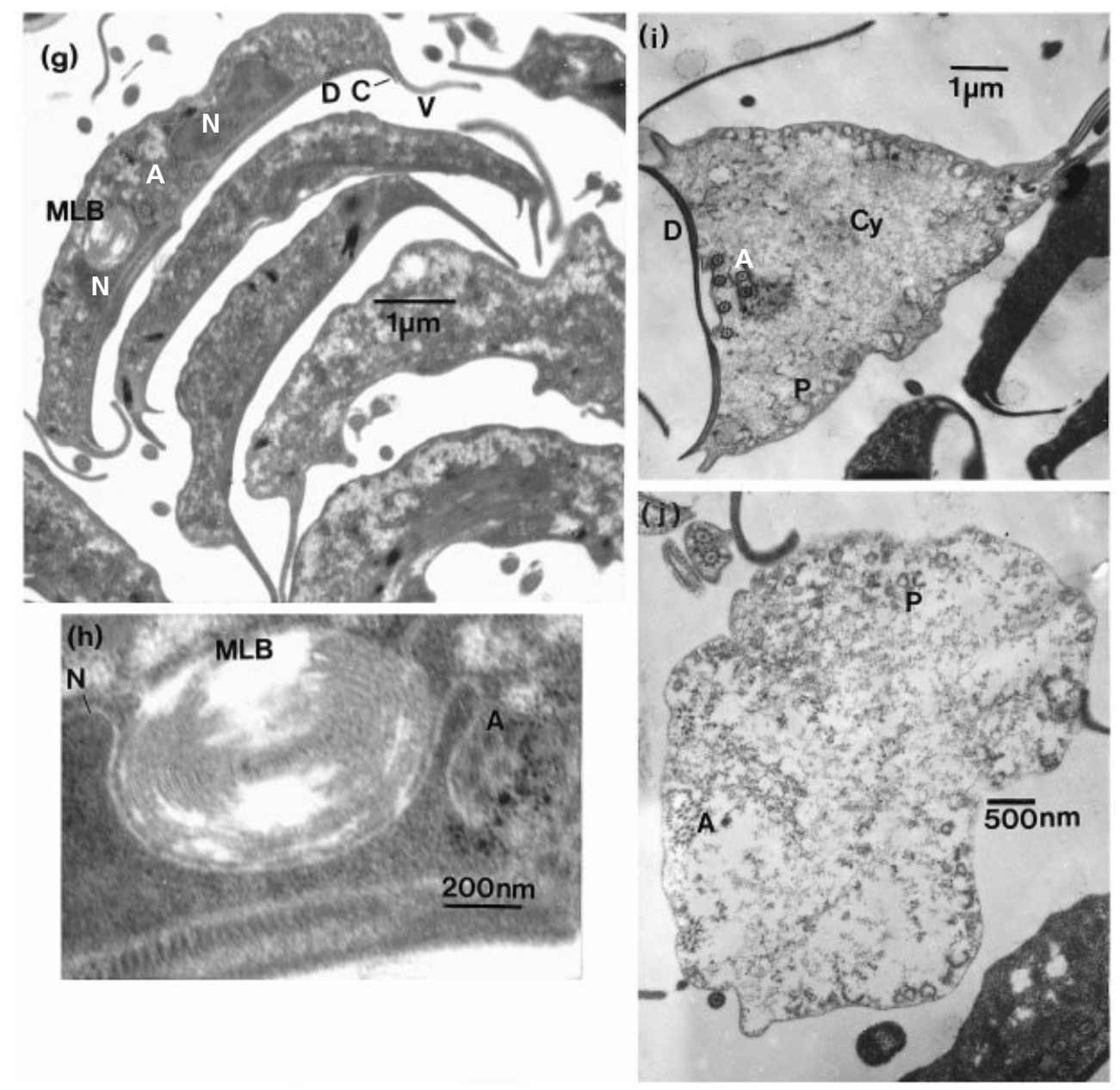

Fig. 6. Electron micrographs of G. intestinalis Portland-1. (a) Vertical section through the ventral surface of a control trophozoite. (b) Horizontal section at the level of the nuclei through a control trophozoite. (c) Vertical section through the ventral surface of a trophozoite incubated with $60 \mu \mathrm{m} \mathrm{H}_{2} \mathrm{O}_{2}$ for $30 \mathrm{~min}$. (d) Horizontal section through a trophozoite incubated with $\mathrm{H}_{2} \mathrm{O}_{2}$ for $30 \mathrm{~min}$. (e, f) Sections through trophozoites that have been aerated for $1 \mathrm{~h}$. $(g, h, i)$ Sections through trophozoites that have been aerated for $2 \mathrm{~h}$. (j) Section through a trophozoite that has been aerated for $3 \mathrm{~h}$. $\mathrm{N}$, nuclei; P, peripheral vesicles; S, striated bodies; D, ventral disc; K, kinetosomal complex; F, funis, M, median body microtubules; A, axonemes; $C$, lateral crest; $V$, ventrolateral flange; AF, anterior flagella; MLB, multilamellar body; Cy, cytoplasm.

vated dyes toluidine blue and rose bengal (Krinsky, 1979), supports the suggestion (Lamberts \& Neckers, 1985 ) that the menadione sensitivity of G. lamblia can also be accounted for by free-radical damage by reactive oxygen species. Thus the anti-giardial effects of a redoxcycling naphothquinone are produced by an amplification of the effects of $\mathrm{O}_{2}$ damage. The anti-giardial effects both of menadione, and of $\mathrm{H}_{2} \mathrm{O}_{2}$ reported here, warrant further investigation as a means of control of this important human pathogen.

\section{ACKNOWLEDGEMENTS}

We are grateful to Dr Kevin Barrow and Mr Till Bocking for advice on singlet oxygen generation. The work was in part supported by a travel grant from the Royal Society to D.L.

\section{REFERENCES}

Aruoma, O. I., Halliwell, B., Gajewski, E. \& Dizdaroglu, M. (1989). Damage to the bases in DNA induced by hydrogen peroxide and ferric ion chelates. J Biol Chem 264, 20509-20512.

Atkinson, H. J. (1980). Respiration. In Nematodes as Biological Models, pp. 101-138. Edited by B. H. Zuckerman. London: Academic Press.

Brown, D. M., Upcroft, J. A. \& Upcroft, P. (1995). Free radical detoxification in Giardia duodenalis. Mol Biochem Parasitol 72, 47-56.

Craun, G. F. (1990). Waterborne giardiasis. In Giardiasis. Human Parasitic Disease, vol. 3, pp. 267-290. Edited by E. A. Meyer. Amsterdam: Elsevier.

Edwards, M. R., Gilroy, F. V., Jiminez, M. B. \& O'Sullivan, W. J. (1989). Alanine is a major end product of metabolism by Giardia 
lamblia: a proton nuclear magnetic resonance study. Mol Biochem Parasitol 37, 19-26.

Ellis, J. E., Williams, R., Cole, D., Cammack, R. \& Lloyd, D. (1993). Electron transport components of the parasitic protozoon Giardia lamblia. FEBS Lett 325, 196-200.

Ellman, G. L. (1959). Method for the modification and quantitative detection of thiol groups. Arch Biochem Biophys 82, 70.

Emri, M., Balkay, L., Krasznai, Z., Tron, L. \& Martin, T. (1998). Wide applicability of a flow cytometric assay to measure absolute membrane potentials on a millivolt scale. Eur Biophys J 28, 78-83.

Halliwell, B. (1978). Superoxide-dependent formation of hydroxyl radicals in the presence of iron chelates. FEBS Lett 92, 321-326.

Halliwell, B. \& Gutteridge, J. M. C. (1989). Free Radicals in Biology and Medicine. Oxford: Oxford University Press.

Keister, D. B. (1983). Axenic culture of Giardia lamblia in TYI-S33 medium supplemented with bile. Trans R Soc Trop Med Hyg 77, 487-488.

Krasznai, Z., Marian, T., Balkay, L., Emri, M. \& Tron, L. (1995). Flow cytometric determination of absolute membrane potential of cells. J Photochem Photobiol B Biol 28, 93-99.

Krinsky, N. I. (1979). Biological roles of singlet oxygen. In Singlet Oxygen, pp. 597-641. Edited by H. H. Wasserman \& R. W. Murray. London: Academic Press.

Lamberts, J. J. M. \& Neckers, D. C. (1985). Rose Bengal derivatives as singlet oxygen sensitizers. Tetrahedron 41, 2183-2190.

Lloyd, D. \& Hayes, A. J. (1995). Vigour, vitality and viability of microorganisms. FEMS Microbiol Lett 133, 1-7.

Lloyd, D., Edwards, S. W., Kristensen, B. \& Degn, H. (1979). The effect of inhibitors on the oxygen kinetics of terminal oxidases of Acanthamoeba castellanii. Biochem J 182, 11-15.

Lundsgaard, J. \& Degn, H. (1973). A digital gas mixer. IEEE Trans Biomed Eng 20, 384-387.
Meyer, E. A. (1976). Giardia lamblia: isolation and axenic cultivation. Exp Parasitol 39, 301-310.

Ortega, Y. R. \& Adam, R. D. (1997). Giardia: overview and update Clin Infect Dis 25, 545-550.

Paget, T., Jarroll, E., Manning, P., Lindmark, D. \& Lloyd, D. (1989). Respiration in the cysts and trophozoites of Giardia muris. J Gen Microbiol 13, 145-154.

Paget, T., Raynor, M. H., Shipp, D. W. E. \& Lloyd, D. (1990). Giardia lamblia produces alanine anaerobically but not in the presence of oxygen. Mol Biochem Parasitol 42, 63-68.

Paget, T., Kelly, M., Jarroll, E., Lindmark, D. \& Lloyd, D. (1993). The effects of oxygen on fermentation in Giardia lamblia. Mol Biochem Parasitol 57, 65-72.

Park, J. H., Schofield, P. J. \& Edwards, M. R. (1995). The role of alanine in the acute response of Giardia intestinalis to hypoosmotic shock. Microbiology 141, 2455-2462.

Shukry, S., Zaki, A. M., Dupont, H. L., Shoukry, I., El Tagi, M. \& Hamed, S. (1986). Detection of enteropathogens in fatal and potentially fatal diarrhea in Cairo, Egypt. Clin Microbiol 24, 959-962.

Smith, H. V., Robertson, L. J., Campbell, A. T. \& Girdwood, R. W. A. (1995). Giardia and giardiasis: what's in a name. Microbiol Eur 3, 22-29.

Smith, N. C., Bryant, C. \& Boreham, D. F. L. (1988). Possible roles for pyruvate-ferredoxin oxidoreductase and thiol-dependent peroxidase and reductase activities in resistance to nitroheterocyclic drugs in Giardia intestinalis. Int J Parasitol 18, 991-997.

Winiecka-Krusnell, J. \& Linder, E. (1998). Cysticidal effect of chlorine dioxide on Giardia intestinalis cysts. Acta Trop 70, 369-372.

Received 7 June 2000; revised 7 August 2000; accepted 21 August 2000. 